\title{
Mechanisms of action, chemical characteristics, and model systems of obesogens
}

\author{
Mallory D. Griffin, Sean R. Pereira, Megan K. DeBari and Rosalyn D. Abbott
}

\begin{abstract}
There is increasing evidence for the role of environmental endocrine disrupting contaminants, coined obesogens, in exacerbating the rising obesity epidemic. Obesogens can be found in everyday items ranging from pesticides to food packaging. Although research shows that obesogens can have effects on adipocyte size, phenotype, metabolic activity, and hormone levels, much remains unknown about these chemicals. This review will discuss what is currently known about the mechanisms of obesogens, including expression of the PPARs, hormone interference, and inflammation. Strategies for identifying obesogenic chemicals and their mechanisms through chemical characteristics and model systems will also be discussed. Ultimately, research should focus on improving models to discern precise mechanisms of obesogenic action and to test therapeutics targeting these mechanisms.
\end{abstract}

Keywords: Obesogens, Endocrine disrupting chemicals, In vitro models, In vivo models, Obesogenic mechanisms, Hormone interference, Inflammation, Chemical characteristics, Model systems

\section{Background}

The economic impact of obesity worldwide is estimated to be $2.8 \%$ of the global gross domestic product [1]. While an imbalance in energy intake and expenditure is largely to blame, other factors contribute to this high economic burden. An analysis of obesity trends (the National Health and Nutrition Examination Study) found that from 1988 to 2006 for the same caloric intake and physical activity, the average BMI was higher [2]. Grun and Blumberg in 2006 [3] hypothesized that this increase in average BMI may be related to obesogens, a subset of endocrine disrupting chemicals (EDCs) that alter metabolism to favor lipid storage, leading to a predisposition to obesity. These chemicals can be found in pesticides, cleaning products, and food and beverage packaging

\footnotetext{
* Correspondence: rabbott@andrew.cmu.edu

Carnegie Mellon University, 5000 Forbes Avenue, Scott Hall, Pittsburgh, PA 15213, USA
}

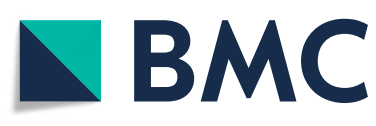

( The Author(s). 2020 Open Access This article is licensed under a Creative Commons Attribution 4.0 International License, which permits use, sharing, adaptation, distribution and reproduction in any medium or format, as long as you give appropriate credit to the original author(s) and the source, provide a link to the Creative Commons licence, and indicate if changes were made. The images or other third party material in this article are included in the article's Creative Commons licence, unless indicated otherwise in a credit line to the material. If material is not included in the article's Creative Commons licence and your intended use is not permitted by statutory regulation or exceeds the permitted use, you will need to obtain permission directly from the copyright holder. To view a copy of this licence, visit http://creativecommons.org/licenses/by/4.0/. The Creative Commons Public Domain Dedication waiver (http://creativecommons.org/publicdomain/zero/1.0/) applies to the data made available in this article, unless otherwise stated in a credit line to the data.
[4]. Regular exposure to these contaminants can have long-term effects on adipose tissue, metabolic activity, hormones, and ultimately weight. Additionally, prenatal exposure may put people at risk for becoming obese later in life. As obesity care is a billion-dollar industry worldwide, identifying and understanding these obesogens is a crucial step in reforming worldwide health.

This review discusses possible mechanisms of obesogenic action including regulation of the PPAR genes, hormone interference, and inflammation. Insights into mechanisms of obesogens will allow for specific therapeutic targeting to minimize effects and aid in predicting potential obesogens from environmental contaminants. This review also discusses advantages and disadvantages of current model systems that are being used (both in vitro and in vivo as well as epidemiological studies) to study obesogens. 


\section{Main text}

\section{Chemical characteristics of obesogens}

Obesogens work through a diverse set of mechanisms [5]. They have been known to mimic or partially mimic natural hormones, having undesired biological effects [6]. They can bind to receptors in the cell membrane, cytosol, or the nucleus affecting cellular responses, peptide hormones, or gene expression directly [6]. Their ability to do this depends on having chemical characteristics that resemble natural hormones including lipophilicity and small molecular weight (Fig. 1). Three key properties that may influence the ability of obesogens to act as xenohormones are the partition constant, half-life, and molecular weight. The partition constant is an equilibrium constant that measures how a compound distributes between two immiscible solvents. The octanol: water partition coefficient $\left(\mathrm{K}_{\mathrm{ow}}\right)$ is the ratio of a compound's partition (divide) between organic matter and water [7]. The equation for $\mathrm{K}_{\mathrm{OW}}$ is defined as: concentration of chemical in octanol phase / concentration of chemical in aqueous phase [7]. The equation gives a measure of how a chemical will split between tissue and serum at equilibrium. As lipids are organic matter, it is thus an accepted measure of the lipophilicity of the compound. A higher $\mathrm{K}_{\mathrm{OW}}$ indicates a more lipophilic substance and a propensity to accumulate in adipose tissue $[6,7]$. The biological half-life of a chemical is the time it takes for half of the amount of the chemical to be broken down or removed from the body. A longer biological half-life indicates longer persistence in the body. This is particularly relevant to obesogens as a longer biological half-life can mean even a brief exposure can have long-term effects [8]. Molecular weight is a measure of the size of the compound. This is important, since smaller molecules can diffuse into adipocytes more easily. Additionally, even high molecular weight chemicals can be broken down into low molecular weight metabolites in the body that can have obesogenic effects [7]. These three properties tend to have a profound effect on accumulation in the body and affinity for receptors [7, 9]. Lipophilic substances with low molecular weights cross cell membranes easily [6]. Those with long biological half-lives can reside in adipose tissue for months to years. Many well-studied obesogens fit these criteria. A short list of established obesogens and their molecular characteristics are given in Table 1. Lipophilic compounds are also more resistant to degradation, leading to many of them having a biphasic half-life such as $2,2^{\prime}, 4,4^{\prime}$-tetrabromodiphenyl ether (BDE-47) (Table 1) [6]. Substances that are biphasic have an elimination curve that is steep that describes the initial distribution of the drug in the body, followed by shallow curve that describes the final removal of drug, which is dependent on the release of the drug from tissue compartments such as adipose tissue into the blood [20]. Obesogens also have a strong affinity for receptors in the body, specifically nuclear receptors. This could be attributed to the lipophilic nature of the compounds that resemble steroid substances found heavily in adipose tissue [21]. However, more studies need to be done to find other physiochemical properties that control EDCs ability to utilize these receptors.

\section{Mechanisms of action of obesogens}

Definitive mechanisms for obesogens are still in the early stages of investigation. Current research points to a major role of peroxisome proliferator-activated receptor

\section{Characteristics}

\section{A. Molecular weight \\ B. Lipophilic}
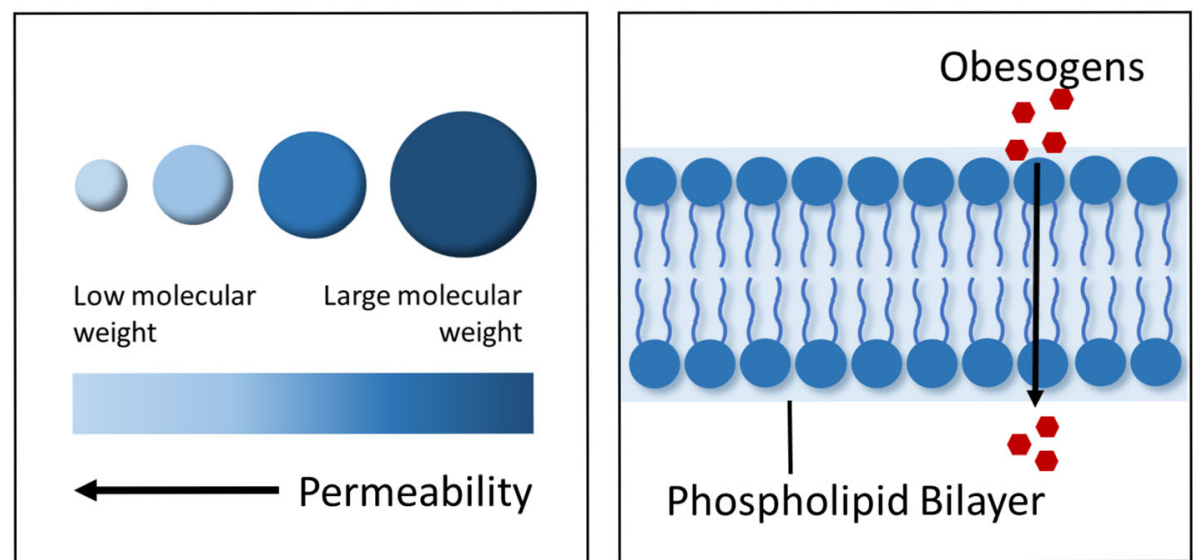

Fig. 1 Obesogens have characteristics that make them well-suited to enter cells including small molecular weight (a) and lipophilicity (b). These properties allow obesogens to easily pass through cell membranes to influence cellular responses and gene expression 
Table 1 Sample list of a subset of well-established obesogens with their partitioning coefficients, half-life, and molecular weight ( $\mathrm{g} / \mathrm{mol}$ ). The octanol/water partitioning coefficient is measured using the log $\mathrm{K}_{\mathrm{ow}}$ value, which indicates the partitioning of a chemical between octanol and water. In these experiments, octanol is used to mimic fat and other hydrophobic components in biological systems. A partitioning coefficient level greater than 1 indicates low solubility in water

\begin{tabular}{|c|c|c|c|c|}
\hline \multirow[t]{2}{*}{ Obesogen Source } & \multirow[t]{2}{*}{ Obesogens $^{\mathrm{a}}$} & \multicolumn{3}{|l|}{ Chemical Characteristics* $^{*}$} \\
\hline & & Partitioning $\left(\mathrm{Log} \mathrm{K}_{\mathrm{ow}}\right)^{\mathrm{b}}$ & Half-life (hours) ${ }^{c}$ & Size $(\mathrm{g} / \mathrm{mol})$ \\
\hline \multirow[t]{8}{*}{ Industrial Chemicals } & Bisphenol A (BPA) & 3.32 & $5.3^{d}[10,11]$ & 228.291 \\
\hline & Bisphenol A diglycidyl ether (BADGE) & $\sim 3.84$ & $120^{\mathrm{e}}[12]$ & 340.419 \\
\hline & Bisphenol S (BPS) & $\sim 1.65$ & $6.93[13]$ & 250.268 \\
\hline & Firemaster 550 (FM550) & $8.80-11.95^{f}$ & Unknown [14] & 549.923 \\
\hline & 2,2',4,4'-Tetrabromodiphenyl ether (BDE-47) & $6.81 \pm 0.08[15]$ & 664 days $^{9}$ & 485.795 \\
\hline & 3,3',4,4'-Tetrachlorobiphenyl (PCB-77) & 6.72 & $152-186[16]$ & 291.980 \\
\hline & Mono-(2-ethylhexyl) phthalate (MEHP) & $4.92^{h}$ & $4.4-6.6^{i}$ & 278.348 \\
\hline & bis(2-ethylhexyl) phthalate (DEHP) & 7.60 & $5^{j}$ & 390.564 \\
\hline \multirow[t]{3}{*}{ Biocides } & Dichlorodiphenyl-trichloroethane (DDT) & 6.91 & $10.6^{\mathrm{k}}$ & 354.476 \\
\hline & Tributyltin (TBT) & $3.90-4.90[17]$ & 23-30 days $[18]$ & 290.058 \\
\hline & Triphenyltin (TPT) & $4.19^{1}$ & 3 days & 385.478 \\
\hline \multirow[t]{2}{*}{ Pharmaceuticals } & Diethylstilbestrol (DES) & 5.07 & 2-3 days [19] & 268.350 \\
\hline & Estradiol (Estrogen steroid Hormone) & 4.01 & 3 days & 272.388 \\
\hline Pollutant & Dioxin & 6.80 & $5-8$ years & 321.970 \\
\hline Smoking & Nicotine & 1.17 & $1-4^{m}$ & 162.236 \\
\hline
\end{tabular}

Sources

*Values of partition coefficients and half-lives might differ from those in this table because of variations in the study such as the location the study was conducted, type of tissue, biphasic pattern, initial dosage, temperature, salinity and $\mathrm{pH}$.

${ }^{a}$ The obesogens discussed are well-established obesogens that have been used in various studies.

${ }^{\mathrm{b}} \mathrm{All}$ values of $\log \mathrm{K}_{\mathrm{ow}}$ were reported at $25^{\circ} \mathrm{C}$ and at a $\mathrm{pH}$ of 7 unless stated otherwise.

'All estimated half-life values reported were conducted on studies in human based models unless stated otherwise.

${ }^{d}$ BPA data are not consistent with the current consensus that BPA exposures are both rapidly cleared and almost entirely related to food intake. Instead, it appears plausible that there is substantial nonfood exposure, accumulation in body compartments with long elimination times, or both [3].

eBisphenol A diglycidyl ether based on Hydrolysis in Water.

f2-ethyl-1-hexyl-2,3,4,5-tetrabromobenzoate (TBB) and bis (2-ethylhexyl) tetrabromophthalate (TBPH) are the two major additive Brominated flame retardants (BFRs) in Firemaster 550. [16].

${ }^{9}$ Tetrabromodiphenyl ether (BDE-47) has two phases of elimination. The first phase of elimination is where the majority of the BDE-47 is eliminated from the body $(67 \%)$, and the remaining BDE-47 is eliminated during the terminal phase. Additionally, elimination, both whole-body and from individual tissues, is biphasic due to varying initial and terminal phase lengths in different tissues. Since BDE-47 is highly lipophilic its terminal phase was primarily dictated by adipose tissue and skin [21].

${ }^{\mathrm{h}}$ MEHP was estimated from $\mathrm{n}$-octanol: water coefficient $\left(\mathrm{K}_{\mathrm{ow}}\right)$ by the algorithm from Poulin and Krishnan (1993). A log $\mathrm{K}_{\mathrm{ow}}$ of 4.92 was estimated based on the chemical structure for nonionized MEHP.

iSingle administration of MEHP in a rat $(0.4 \mathrm{~g} / \mathrm{kg})$ resulted in plasma concentrations of $84.1+/-14.9 \mathrm{micrograms} / \mathrm{ml} 3 \mathrm{~h}$ after dosing; the half-life of MEHP was 5.5 $+/-1.1$ h. [22].

${ }^{j}$ After an absorption and distribution phase of 4 to $8 \mathrm{~h}$, half-life times of excretion in the first elimination phase were approximately $2 \mathrm{~h}$; Half-life times in the second phase-beginning 14 to $18 \mathrm{~h}$ post dose-were $5 \mathrm{~h}$ for MEHP [23].

${ }^{\mathrm{k}}$ Female rats were dosed orally with (14) C-ring-labeled p,p'-DDT during pregnancy or lactation. Average half-life was $10.6 \mathrm{~h}$ in tissues and in the fetus.

'Triphentylin Chloride was used to find the log $\mathrm{K}_{\text {ow }}$.

${ }^{m}$ Nicotine's half-life in the initial phase is reportedly about 2-3 min and the half-life in the terminal phase averages about $2 \mathrm{~h}$.

Note: All partitioning coefficient values $>1$ indicate lipophilic properties (bold). Half-life with strong indication of biphasic pattern (bold). Non-asterisk and cited chemical characteristics were obtained from the U.S. National Library of Medicine Open Chemistry Database and the International Programme on Chemical Safety.

gamma (PPARY), hormone interference, and inflammation in obesogenic outcomes (Fig. 2). While the role of these three mechanisms in obesogenic effects will be discussed in the following section, it should be noted that many potential mechanisms for obesogens exist, not all of which will be discussed here. It should also be noted that there are likely distinct pathways for developmental (in utero) and non-developmental exposures of obesogens, as well as persistent versus non-persistent exposures, with more research required to clearly define these differences. For more comprehensive reviews on what is currently known about mechanisms of obesogens see [22-24].

\section{Activation of peroxisome proliferator-activated receptor gamma (PPARY)}

Peroxisome proliferator activated receptors (PPARs) are a group of non-steroid nuclear hormone receptors [25, 26]. There are three known isoforms of PPAR: (1) PPAR $\alpha$; (2) PPAR $\beta / \delta$; and (3) PPAR $\gamma$. Each isoform is encoded by a separate gene [26, 27]. PPARs bind with 


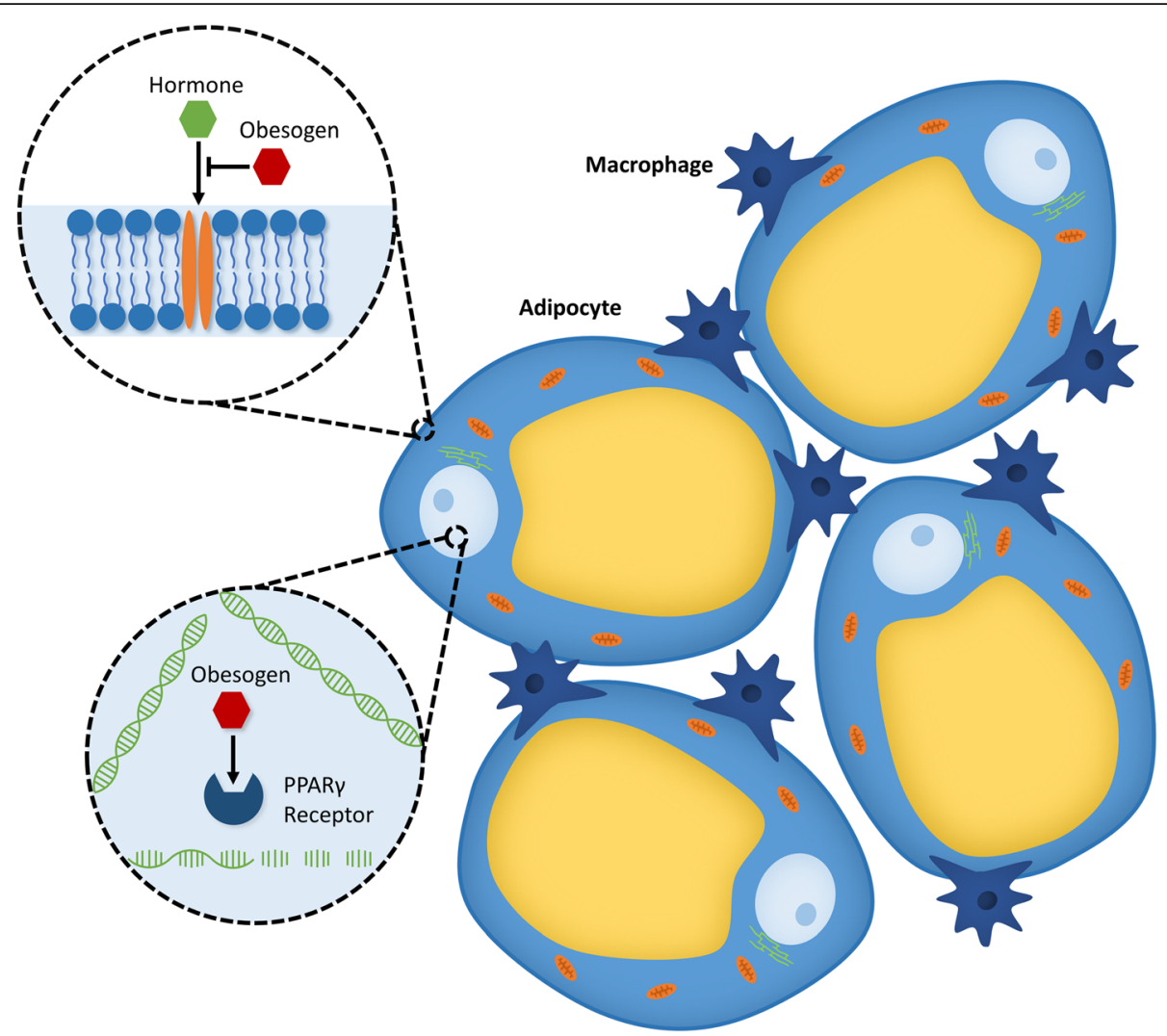

Fig. 2 Obesogens can interfere with endocrine function by direct hormone interference or activation of peroxisome proliferator-activated receptor gamma (PPARY) in adipocytes. Obesogens can also alter appetite and satiety through neuroendocrine mechanisms

the nuclear receptor 9-cis retinoic acid receptor (RXR) to form their own heterodimers. These heterodimers modulate expression of target genes [28-31]. The heterodimer binds to specific response sites called peroxisome proliferator response elements (PPRE) in the promoter region of target genes. Subsequent binding of a ligand to the receptor then alters the conformation of PPAR to induce recruitment of co-transcription factors. This results in an increase in mRNA expression of the target gene [28, 29, 31, 32]. PPARs target genes related to lipid storage, transport, and metabolism including fibroblast growth factor 1 (FGF1) (PPARY) [33], Gprotein-coupled receptor 81 (GPR81) (PPAR $\gamma$ ) [34], adiponectin (PPAR $\alpha)$, [35], and CPT-1 (PPAR $\alpha)[36,37]$ and so are common targets in the study of obesogenic mechanisms [28, 29, 31].

PPARy is the most widely studied transcription factor in terms of adipose tissue development and is required for adipogenesis [38-40]. Thiazolidinedione drugs used to treat type 2 diabetes target PPARy to increase insulin sensitivity with the side effect of inducing adipogenesis [41]. Many obesogens have already been shown to upregulate this gene. Tributyltin (TBT), one of the most widely studied obesogens, activates the PPAR $\gamma / \mathrm{RXR}$ heterodimer in vitro [42, 43], in utero [44], and in vivo [43]. It is unclear if the effects are due to the activation of the PPAR $\gamma$ domain itself, the RXR domain, or both. It is likely that TBT activates the PPAR $/ \mathrm{RXR}$ complex through binding of the RXR domain since transfected Cos7 cells were activated by TBT in the presence of a PPARy antagonist [42]. Additionally, commitment of mesenchymal stem cells to the adipogenic lineage has been shown to be dependent on RXR activation and not PPARY activation [45]. However, further analysis needs to be done to affirm this conclusion. Other obesogens that have also been shown to act at least partially through PPAR $/$ RXR activation include bisphenol A (BPA, plastic monomer) [46-48], triflumizole (fungicide) [49], phthalate monoesters (plasticizers) [50], Firemaster 550 (flame retardant) [51], and dioctyl sodium sulfosuccinate (DOSS) (component of oil dispersant COREXIT) [52]. It is likely that different obesogens have different mechanisms for activating the PPAR $\gamma /$ RXR heterodimer and further research will be needed to determine specific molecular mechanisms. Understanding the specific effects of these obesogens on the PPAR $\gamma /$ RXR heterodimer may provide valuable insight for reversing obesogenic effects. 
PPAR $\alpha$ is another isoform of PPAR. It is found primarily in the liver, skeletal muscle, heart, and brown adipose tissue and plays a major role in fatty acid metabolism in the liver [53-55]. Natural ligands include oxidized phospholipids, lipoprotein lipolytic proteins, and fatty acids, among other natural ligands [54]. Although it is found primarily in liver and skeletal muscle, there is increasing evidence for its role in adipose tissue and as a target for obesogens. PPAR $\alpha$ is known to improve insulin sensitivity and aid in body weight control in rodents $[53,54]$. Agonists have also been shown to reduce insulin resistance and decrease body weight in male mice [53]. PPAR $\alpha$-deficient mice have been shown to have upregulated mRNA expression of adiponectin, but this is thought to be the result of increased adipose tissue mass or an attempt to counterbalance a concomitant increase in leptin expression [56]. PPAR $\alpha$ is not as widely studied as PPARY in terms of obesogens but current literature suggests there is an effect. Monosodium glutamate (MSG) and aspartame decreased gene expression of PPAR $\alpha$ in mice [57]. TBT was shown to activate PPAR $\alpha$ in transfected HeLa cells [58] and mice exposed to TBT in utero showed increased mRNA expression of PPAR $\alpha$ [59]. Since PPAR $\alpha$ is known to improve insulin sensitivity, the increased expression could be one of the mechanisms for obesogenic effects. However, the obesogen bis (2-ethylhexyl) phthalate (DEHP) increased mRNA expression of PPAR $\alpha$ in liver tissue while decreasing expression in visceral fat in mice [60]. The mechanisms of obesogens are likely more complex than what is currently understood and further research will be required to draw conclusions.

\section{Hormone interference}

Exogenous chemicals that are capable of mimicking or interfering with hormonal action can have profound effects on the overall function of metabolic processes. Hormones such as androgens and estrogens are tightly regulated and play an important role in the function of adipose tissue. Increasing androgen levels are associated with lower BMIs in men [61]. Several phthalates are suspected antiandrogens [62] and have shown obesogenic effects in humans. BPA acts as a xenoestrogen. When mice are exposed perinatally to BPA, the offspring are significantly heavier [48]. Dichlorodiphenyldichloroethylene (DDE, a metabolite of the common pesticide dichlorodiphenyl-trichloroethane, DDT) has also been shown to exhibit estrogenic responses [63]. It leads to rapid weight gain in infants after prenatal exposure. BPA, phthalates and polybrominated diphenyl ethers (PBDEs) also have been shown to reduce circulating thyroid levels [64], a key regulator of basal metabolism. Decreased thyroid hormone levels result in an increased BMI [65]. Leptin and adiponectin are also influenced by obesogens. Leptin, discovered by Zhang et al., is responsible for satiety and increases glucose uptake by skeletal muscle and brown adipose tissue [66, 67]. Mutations in leptin result in obesity and hyperinsulinemia. However, hyperleptinemia, as is common in obesity, can lead to leptin resistance [66, 68]. Adiponectin, first discovered by Scherer et al., is known to increase insulin sensitivity $[69,70]$. Multiple obesogens have been shown to have an effect on these hormones. TBT increases plasma leptin levels in mice, causing an overexpression of the leptin gene, and decreased serum adiponectin levels [71, 72]. DEHP decreases both adiponectin and leptin mRNA levels in mice [60]. DOSS increases plasma leptin levels in male mice exposed in utero [73]. Genistein, an isoflavone found in soy, induced adipose deposition in male mice, increased insulin resistance, and upregulated mRNA expression of leptin [74]. DEHP has also been shown to increase serum leptin levels [75]. Benzyl butyl phthalate (BBP, plasticizer) was shown to increase adiponectin protein expression in differentiated 3T3-L1 cells [76]. Additionally, glucocorticoid receptor signaling is crucial for adipocyte differentiation [77]. Sargis et al. [78] demonstrated increased adipogenic differentiation via glucocorticoid receptor activation with BPA, dicyclohexyl phthalate (DCHP), endrin, and tolylfluanid (TF). Hormones are a common target of obesogens but the exact effect of each obesogen and the mechanisms of hormone influence are yet to be determined. Moreover, there are likely other hormonal targets that are still unidentified.

\section{Inflammation}

Obesity is associated with chronic inflammation. While inflammation is associated with adipose tissue expansion, it may also be the result of epigenetic changes due to environmental and lifestyle factors [79]. DOSS has been shown to increase body mass, visceral fat mass, upregulate inflammatory gene expression (Cox2, Nox4), and increase plasma levels of IL-6 in male mice exposed in utero [73]. Likewise, TBT exposure in rats upregulated PPAR $\gamma$, increased ovarian fat mass, and increased reproductive tract inflammation in rats [80]. A similar study in female rats showed increased body weight and uterine inflammation after TBT exposure [81]. Male mice exposed to BPA showed increased gene expression of IL-6, TNF- $\alpha$, and IL- $1 \beta$ in white adipose tissue and increased fat mass on a chow-diet [82]. Differentiated 3T3-L1 preadipocytes also show increased expression of IL-6, TNF$\alpha$, MCP-1, and CXCL1 after exposure to either TBT, BPA, or mono-ethylhexyl phthalate (MEHP, metabolite of DEHP) [83]. Moreover, a study on male mice showed an Il-17 antibody was able to reduce inflammation and counter the obesogenic effects of BPA, suggesting inflammation plays a major role in the obesogenic effects 
of BPA [84]. Multiple obesogens have also been shown to increase the presence of immune cells in adipose tissue. Female sheep exposed to BPA show increased mRNA expression of CD68, a marker of macrophage infiltration [85]. Additionally, mice exposed to BPA perinatally showed increased presence of macrophages in gonadal white adipose tissue [86]. BPA has also been shown to increase macrophage self-renewal [87]. BPA is one of the most widely studied obesogens but it is likely that an influx of inflammatory cells plays a role in other obesogens as well. There is also evidence for a correlation between the PPAR genes and inflammation. While they are upregulated during inflammation they also act as negative feedback loops by being antagonists to transcription factors for proinflammatory genes [88-92]. Antidiabetic drugs, such as thiazolidinediones antagonize tumor necrosis factor- $\alpha$ (TNF- $\alpha$ ) [93] and act as agonists for PPARy [94]. This area is in early stages of research but suggests a role for inflammatory cells and gene expression in obesogenic modes of action.

\section{Model systems}

Currently, model systems are used to test mechanisms of obesogenic action including in vitro and in vivo systems as well as epidemiological studies. Each type poses unique benefits and drawbacks to establishing mechanisms. Common systems for each type are discussed below along with advantages and disadvantages.

\section{In vitro models}

In vitro models pose several benefits over other model systems. They can utilize human cell types to be more physiologically relevant. They are also generally simpler, faster, can be done in parallel (for medium to high throughput analyses), and are more cost-effective, making them a good screening mechanism for obesogens prior to in vivo studies. Currently, there are several in vitro models to screen potential obesogens that examine characteristics such as adipocyte maturation and lipid accumulation (Table 2). The vast majority of these models utilize mouse 3T3-L1 preadipocytes. These cultures have been integral in elucidating certain molecular mechanisms of adipogenesis. However, it is still unclear if the 3T3-L1 cell line is adequate for evaluating adipogenic responses, since they are fully committed to the adipocyte lineage $[120,121]$. Additionally, the murinederived 3T3-L1 cell line maintains species specificity, which may hinder application of results for humanbased risk assessments. Use of human primary cell lines mitigates this risk but further limitations exist. Patient demographics and medical histories are unknown to researchers and contribute large variability in outcomes [122]. Sex specific differences are often not accounted for and gender is known to dictate body fat storage
[123] and responses to obesogens [48]. Future work needs to work on validating these models using primary cells or tissues from a wide range of known patient demographics. There are also depot-specific effects of obesogens on adipose tissue. Cells derived from visceral versus subcutaneous or brown versus white adipose tissue may have varying responses to obesogens. As visceral adipose tissue is most closely linked to metabolic disease, understanding differential responses by adipose tissue depots is crucial for defining obesogenic effects.

To better understand the impact of obesogenic chemicals in more physiologically relevant environments, scientists have been examining 3D human tissue systems to model the effects of obesogens in vitro (Table 2). 3D adipose tissue systems recapitulate the in vivo adipose tissue microenvironment, can be extended for long term culture [122, 124] (months, to study chronic effects of obesogens) and can incorporate multiple cell types. They can be used to study the sequestration of obesogens in adipose tissue as well as cell migration. Obesogens are primarily lipophilic and thus prone to retention by adipose tissue [125]. 3D models can incorporate mature adipocytes which are non-adherent and cannot be cultured using standard 2D culture techniques. Similarly, they allow for long-term in vitro study of ASC differentiation which also become non-adherent over time [126]. The use of 3D models allows for more sophisticated coculture systems. As multiple organs play a role in obesogenic actions including adipose tissue, pancreas, liver, thyroid, etc., systems integrating multiple cell types may provide more physiologically accurate data. They can also study paracrine signaling. However, 3D models increase cost and complexity over 2D systems, since they use natural or artificial extracellular matrices (ECM). This brings the added variables of cell binding domains, mechanical properties, pore size, etc. Perfusion cultures also pose issues related to flow rates, media, and fluid/cell ratios. Finally, most in vitro studies are currently $2 \mathrm{D}$ which limits the ability to compare results from 3D cultures to alreadyestablished models. Overall, both 2D and 3D in vitro models provide precise control of cellular interactions and boundary conditions, permitting quantitative analyses of mechanisms. They are ideally suited for highthroughput screening as they can test dose responses and mixture effects in parallel. While in vitro models have limitations that must be resolved, they provide strong screening potential for obesogens.

\section{In vivo models}

Animal models have the distinct and obvious disadvantage of not accurately replicating human physiology. However, animal models are an important and widely 
Table 2 2D and 3D in vitro models for studying obesogens. Note: -- under Matrix indicates a 2D cell culture study

\begin{tabular}{|c|c|c|c|}
\hline Matrix & Cell Type & Obesogen & Source \\
\hline \multirow[t]{29}{*}{-} & \multirow[t]{13}{*}{ 3T3-L1 (murine preadipocyes) } & Tributyltin (TBT) & $\begin{array}{l}{[42,43,} \\
94-99]\end{array}$ \\
\hline & & Bisphenol A (BPA) & [97-99] \\
\hline & & Bisphenol S (BPS) & [102] \\
\hline & & $\begin{array}{l}\text { Bisphenol A diglycidyl ether } \\
\text { (BADGE) }\end{array}$ & {$[100]$} \\
\hline & & Triphenyltin & [95] \\
\hline & & $\begin{array}{l}\text { Dioctyl sodium sulfosuccinate } \\
\text { (DOSS) }\end{array}$ & {$[52]$} \\
\hline & & Geneistein \& naringenin & [103] \\
\hline & & Phthalate monoesters & {$[32]$} \\
\hline & & 4-nonylphenol (NP) & [101] \\
\hline & & Mono-ethylhexyl phthalate (MEHP) & {$[50]$} \\
\hline & & Flavanone & [104] \\
\hline & & Bixin, norbixin & [105] \\
\hline & & Emodin & [106] \\
\hline & C2C12 (murine) & Mono-ethylhexyl phthalate (MEHP) & {$[50]$} \\
\hline & HELA (human) & Mono-ethylhexyl phthalate (MEHP) & {$[50]$} \\
\hline & Human embryonic kidney cells (HEK293C) & $\begin{array}{l}\text { Dioctyl sodium sulfosuccinate } \\
\text { (DOSS) }\end{array}$ & [52] \\
\hline & HepG2 (human liver carcinoma cells) & $\begin{array}{l}\text { Bisphenol A (BPA), Bisphenol S } \\
\text { (BPS) }\end{array}$ & [102] \\
\hline & \multirow[t]{2}{*}{ Human adipose-derived stem cells (hASCs) } & $\begin{array}{l}\text { Bisphenol A (BPA), Bisphenol A } \\
\text { diglycidyl ether (BADGE) }\end{array}$ & [102] \\
\hline & & Tributyltin (TBT) & [44] \\
\hline & \multirow[t]{2}{*}{ Murine adipose derived stem cells (mASCs) } & $\begin{array}{l}\text { Bisphenol A (BPA), Bisphenol A } \\
\text { diglycidyl ether (BADGE) }\end{array}$ & [102] \\
\hline & & Tributyltin (TBT) & [44] \\
\hline & Fao (murine hepatoma cells) & Phthalate monoesters & {$[32]$} \\
\hline & \multirow[t]{3}{*}{ COS (monkey kidney-derived cells) } & $\begin{array}{l}\text { Bisphenol A (BPA), Bisphenol A } \\
\text { diglycidyl ether (BADGE) }\end{array}$ & [102] \\
\hline & & MBzP, MBuP & [50] \\
\hline & & Mono-ethylhexyl phthalate (MEHP) & {$[50,107]$} \\
\hline & THP-1 macrophages (human) & Psi-baptigenin, hesperidin & [108] \\
\hline & TARM-Luc (human, transfected T47-D epithelial cells) & Monosodium glutamate (MSG) & [109] \\
\hline & KS483 (murine calvaria) & Soy phytoestrogen genistein & [110] \\
\hline & C57BL/6 (murine-derived bone marrow stromal cells) & Firemaster 550 & [51] \\
\hline collagen embedded silk scaffolds & Human embryonic-derived stem cells (hESCs) & $\begin{array}{l}\text { Tributyltin (TBT), Bisphenol A (BPA), } \\
\text { Bisphenol S (BPS) }\end{array}$ & [111] \\
\hline silk scaffolds & $\begin{array}{l}\text { Human adipose-derived stem cells (hASCs), Human umbil- } \\
\text { ical vein endothelial cells (HUVECs) }\end{array}$ & - & [112] \\
\hline silk fibroin matrices & Human adipose-derived stem cells (hASCs) & - & [113] \\
\hline collagen type 1 & $\begin{array}{l}\text { OP9 (murine mesenchymal stromal pluripotent cells), } \\
\mathrm{HaCaT} \text { (human keratinocytes) }\end{array}$ & Super Hatomugi (SPH) & [114] \\
\hline bacterial nanocellulose & Murine mesenchymal stem cells (mMSCs) & - & [115] \\
\hline $\begin{array}{l}\text { fibrous polyethylene teraphthalate } \\
\text { scaffolds }\end{array}$ & 3T3-L1 (murine preadipocyes) & - & [116] \\
\hline low-shear rotary bioreactor & Murine adipose-derived stem cells (mASCs) & - & [117] \\
\hline
\end{tabular}


Table 2 2D and 3D in vitro models for studying obesogens. Note: -- under Matrix indicates a 2D cell culture study (Continued)

\begin{tabular}{llll}
\hline Matrix & Cell Type & Obesogen & Source \\
\hline polyglycolic acid fiber meshes & 3T3-L1 (murine preadipocyes) & - & {$[118]$} \\
$\begin{array}{l}\text { adipospheres created via magnetic } \\
\text { nanoparticle levitation system }\end{array}$ & 3T3-L1 (murine preadipocyes) & - & {$[119]$} \\
\hline
\end{tabular}

used tool for the study of obesogens because they are suited for studying whole body kinetics and systemic effects not possible in vitro. Metabolism and weight is regulated by complex interconnected pathways involving multiple organs including adipose tissue, liver, pancreas, muscle, brain, etc. [127]. Although in vitro cell culture techniques can use human cell lines, recapitulating the inter-dependency of these systems remains difficult. Long-term in vitro culture remains a challenge and multi-organ models pose unique problems such as scaling ratios, common mediums, and organ-specific ECMs. Thus, although more sophisticated in vitro models are being heavily researched, animal models still play an important role in identifying obesogens and understanding obesogenic mechanisms because they allow for the study of organ cross-talk and systemic effects. This is particularly relevant in understanding the role of chronic inflammation and hormone interference.

Rodents are the most commonly used animal model for studying obesogens. Multiple obesogens have been identified using murine models including: TBT [43], BPA [82], triphenyltin [43, 95], DEHP [128], DES [129], MEHP [130], polycyclic aromatic hydrocarbons [131, 132], DDT [133], and nicotine [134]. Mice are biologically and anatomically similar to humans and contract many of the same diseases [135]. This is particularly useful for diseases with an inflammatory component, such as obesity [136], as animal models can mimic complex inflammatory responses. Mice can also be genetically manipulated, inbred to yield genetically identical strains, can be grown under controlled conditions (i.e high-fat/ western diet), and have an accelerated lifespan (minimizing the time required to do studies). Other common in vivo systems used to evaluate obesogens include: rats, [137-139] zebrafish, [140-142] and the Xenopus laevi [143]. Use of in vivo models to study endocrine disruption has provided many insights into potential obesogens and different modes of action. However, it is important to keep in mind the drawbacks of using animal models. As discussed, they do not necessarily recapitulate human physiology [144]. Moreover, the dose-response may not translate directly to humans. The window of exposure may also be unnatural. Mice exposed to a specified level of one particular chemical over the course of weeks may not represent chronic fluctuating exposure to multiple chemicals over the course of years in humans. Animal models play an important role in identifying obesogens and discerning mechanisms of action but should be combined with information from in vitro studies and epidemiological studies to draw the most accurate conclusions.

\section{Epidemiological studies}

Epidemiological studies are extremely important for correlating disease outcomes to concentrations of obesogens in humans. However, human studies linking EDCs and obesity are limited, inconsistent, and lack data to support the growing animal literature (for review see Hatch et al., 2010 [145]). Current studies are often cross-sectional and exploratory.

Since a significant amount of evidence suggests that prenatal exposures predispose patients towards obesity, measurements of obesogens during pregnancy is a large focus for epidemiological studies. A study revealed that increasing maternal urinary phthalate concentrations during pregnancy doubled the likelihood of the offspring being overweight or obese [146]. Likewise, cohort studies on the effects of prenatal exposures to BPA showed an association with an increased waist circumference, BMI, and risk of being obese [147]. Future work is necessary to compare results from developmental exposures to exposures later in life. Perspective long term studies are also necessary to track patients over time.

Some epidemiological studies examine single-spot urine or 24-h urine samples in order to assess exposure over a day [148]. This method allows investigators to directly measure individual chemical concentrations in a variety of biospecimens [149]. However, it is not possible to determine whether exposures were acute or long term. Although chemical exposure biomarkers have been advantageous in studying a variety of individual biospecimens, short half-lives in certain obesogens (such as BPA that persists as BPA-G) and reverse causality due to pharmacokinetic variables have limited their usefulness [150]. Additionally, given the lipophilic nature of obesogens, it is unlikely that urine samples are an accurate reading of exposure. Ideally, adipose tissue would be sampled directly.

Another important consideration brought up by Sharpe and Drake [151], is the influence of confounding factors in epidemiological studies. They warn that obesogenic exposures may not have a causal relationship with obesity, since a Western style diet increases exposure to these compounds, and thus the observed increase in 
levels would be reflective of greater food consumption. Another confounding factor is that many epidemiological studies are designed to assess the impact of a single chemical without accounting for the effects of mixtures [148]. Statistical models must be developed in order to elucidate the health outcomes associated with specific chemicals in the mixtures. These studies should account for the fact that some of these chemicals may operate by the same mechanism, while interfering with other mechanisms.

\section{Conclusion}

Abundant evidence supports the role of exogenous chemicals in rising obesity rates through regulation of gene expression (such as the PPARs), hormone changes, and inflammation. A greater understanding of obesogenic mechanisms will lead to better prophylactic and therapeutic strategies and identify other potential obesogens. In vitro models are useful screening tools for identifying and testing mechanisms of obesogens. Specifically, they can help discern changes to gene expression or molecular pathways that induce changes to adipocyte phenotype. Improvements to these models will also improve in vitro to in vivo extrapolation to humans. Still, animal models remain a useful and generally physiologically accurate tool for testing inter-organ obesogenic mechanisms including hormone interference and inflammation. To validate in vitro and in vivo animal models, more comparisons should be made to epidemiological studies. Epidemiological studies provide unparalleled insight into human obesogen exposures and effects. They can be used to identify exposure levels of potential obesogens and to analyze correlative effects between exposure level and BMI, adiposity, leptin/adiponectin levels, etc. This can help determine if there are safe levels of exposure to specific levels or whether drastic actions should be taken to remove a compound entirely. Integrating the information obtained from all three of these model systems will lead to better-informed choices of compounds that can be used in food processing, packaging, etc. to replace obesogens. Ultimately, this will decrease the economic burden of obesity.

\footnotetext{
Abbreviations

PPAR: Peroxisome proliferator-activated receptor; PPARy: Peroxisome proliferator-activated receptor gamma; PPAR $\beta / \delta$ : Peroxisome proliferatoractivated receptor beta/delta; PPARa: Peroxisome proliferator-activated receptor alpha; EDC: Endocrine disrupting chemical; $\mathrm{K}_{\mathrm{ow}}$ : Partition coefficient; PPRE: Peroxisome proliferator response elements; RXR: Retinoic acid receptor; FGF1: Fibroblast growth factor 1; GPR81: GProtein-coupled receptor 81; BDE-47: 2,2',4,4'-tetrabromodiphenyl ether; BPA: Bisphenol A; TBT: Tributyltin; DOSS: Dioctyl sodium sulfosuccinate; MSG: Monosodium glutamate; DEHP: Di-2-ethylhexyl phthalate; BMI: Body mass index; DDE: Dichlorodiphenyldichloroethylene;

DDT: Dichlorodiphenyl-trichloroethane; PBDEs: Polybrominated diphenyl ethers; BBP: Benzyl butyl phthalate; IL-6: Interleukin-6; TNF-a: Tumor necrosis factor-alpha; IL-1 $\beta$ : Interleukin-1 beta; MCP-1: Monocyte chemoattractant protein-1 CXCL1: C-X-C Motif Chemokine Ligand 1;
}

MEHP: Mono-(2-ethylhexyl) phthalate IL-17: Interleukin-17; BPAG: Bisphenol A $\beta$-D-glucuronide; FM550: Firemaster 550;

DES: Diethylstilbestrol; DCHP: Dicyclohexyl phthalate; TF: Tolylfluanid

\section{Acknowledgements}

Not applicable.

\section{Authors' contributions}

MDG was a major contributor of the conception, design, and drafting of the manuscript. SRP did the literature review, table construction, and manuscript text for the section "Chemical Characteristics of Obesogens." MKD was responsible for figure design and construction as well as critical editing for content. RDA was involved in the conception, design, and drafting of the manuscript. All authors revised the manuscript critically for important intellectual content; gave their final approval of the version to be published; and are accountable for the accuracy and integrity of the work.

\section{Funding}

No funding was obtained for this study.

Availability of data and materials

Not applicable.

Ethics approval and consent to participate

Not applicable.

\section{Consent for publication}

Not applicable.

\section{Competing interests}

The authors declare that they have no competing interests.

Received: 6 June 2019 Accepted: 7 April 2020

Published online: 30 April 2020

\section{References}

1. Tremmel M, Gerdtham U-G, Nilsson PM, Saha S. Economic burden of obesity: a systematic literature review. Int J Environ Res Public Health. 2017:14:435-52.

2. Brown RE, Sharma AM, Ardern Cl, Mirdamadi P, Mirdamadi P, Kuk JL. Secular differences in the association between caloric intake, macronutrient intake, and physical activity with obesity. Obes Res Clin Pract. 2016;10:243-55.

3. Grun F, Blumberg B. Environmental obesogens: organotins and endocrine disruption via nuclear receptor signaling. Endocrinology. 2006:147:S50-5.

4. Sifakis S, Androutsopoulos VP, Tsatsakis AM, Spandidos DA. Human exposure to endocrine disrupting chemicals: effects on the male and female reproductive systems. Environ Toxicol Pharmacol. 2017;51:56-70.

5. Kelishadi R, Poursafa P, Jamshidi F. Role of environmental chemicals in obesity: a systematic review on the current evidence. J Environ Public Health. 2013:2013:896789.

6. Vandenberg LN, Colborn T, Hayes TB, Heindel JJ, Jacobs DR Jr, Lee DH, Shioda T, Soto AM, vom Saal FS, Welshons WV, et al. Hormones and endocrine-disrupting chemicals: low-dose effects and nonmonotonic dose responses. Endocr Rev. 2012;33:378-455

7. Jackson E, Shoemaker R, Larian N, Cassis L. Adipose tissue as a site of toxin accumulation. Comprehensive Physiology. 2017;7:1085-135

8. Lee YM, Kim KS, Jacobs DR, Lee DH. Persistent organic pollutants in adipose tissue should be considered in obesity research. Obes Rev. 2017;18:129-39.

9. Parker MA, Kurrasch DM, Nichols DE. The role of lipophilicity in determining binding affinity and functional activity for 5-HT2A receptor ligands. Bioorg Med Chem. 2008;16:4661-9.

10. Genuis SJ, Beesoon S, Birkholz D, Lobo RA. Human excretion of bisphenol a: blood, urine, and sweat (BUS) study. J Environ Public Health. 2012;2012: 185731.

11. Stahlhut RW, Welshons WV, Swan SH. Bisphenol a data in NHANES suggest longer than expected half-life, substantial nonfood exposure, or both. Environ Health Perspect. 2009;117:784-9.

12. Lane RF, Adams CD, Randtke SJ, Carter RE Jr. Bisphenol diglycidyl ethers and bisphenol a and their hydrolysis in drinking water. Water Res. 2015;72:331-9.

13. Oh J, Choi JW, Ahn YA, Kim S. Pharmacokinetics of bisphenol S in humans after single oral administration. Environ Int. 2018;112:127-33. 
14. Roberts SC, Macaulay LJ, Stapleton HM. In vitro metabolism of the brominated flame retardants 2-ethylhexyl-2,3,4,5-tetrabromobenzoate (TBB) and bis (2-ethylhexyl) 2,3,4,5-tetrabromophthalate (TBPH) in human and rat tissues. Chem Res Toxicol. 2012;25:1435-41.

15. Zhou SN, Buchar A, Siddique S, Takser L, Abdelouahab N, Zhu J. Measurements of selected brominated flame retardants in nursing women: implications for human exposure. Environ Sci Technol. 2014;48: 8873-80.

16. Saghir SA, Koritz GD, Hansen LG. Short-term distribution, metabolism, and excretion of 2,2',5-tri-, 2, 2',4,4'-tetra-, and 3,3',4,4'-tetrachlorobiphenyls in prepubertal rats. Arch Environ Contam Toxicol. 1999;36:213-20.

17. Bangkedphol S, Keenan HE, Davidson C, Sakultantimetha A, Songsasen A. The partition behavior of tributyltin and prediction of environmental fate, persistence and toxicity in aquatic environments. Chemosphere. 2009;77:1326-32.

18. Ema M, Harazono A, Miyawaki E, Ogawa Y. Effect of the day of administration on the developmental toxicity of tributyltin chloride in rats. Arch Environ Contam Toxicol. 1997;33:90-6.

19. Reed CE, Fenton SE. Exposure to diethylstilbestrol during sensitive life stages: a legacy of heritable health effects. Birth Defects Research Part C Embryo Today-Reviews. 2013;99:134-46.

20. Oberg M, Sjodin A, Casabona H, Nordgren I, Klasson-Wehler E, Hakansson H. Tissue distribution and half-lives of individual polychlorinated biphenyls and serum levels of 4-hydroxy-2,3,3',4',5-pentachlorobiphenyl in the rat. Toxicol Sci. 2002;70:171-82.

21. Janesick AS, Blumberg B. Obesogens: an emerging threat to public health. Am J Obstet Gynecol. 2016;214:559-65.

22. Egusquiza RJ, Blumberg B. Environmental Obesogens and their impact on susceptibility to obesity: new mechanisms and chemicals. Endocrinology. 2020;161.

23. Heindel JJ, Blumberg B. Environmental Obesogens: mechanisms and controversies. Annu Rev Pharmacol Toxicol. 2019;59:89-106.

24. Yang O, Kim HL, Weon II, Seo YR. Endocrine-disrupting chemicals: review of toxicological mechanisms using molecular pathway analysis. J Cancer Prev. 2015;20:12-24

25. Chandra V, Huang P, Hamuro Y, Raghuram S, Wang Y, Burris TP, Rastinejad F. Structure of the intact PPAR- $\gamma-R X R-a$ nuclear receptor complex on DNA. Nature. 2008;456:350-6.

26. Berger J, Moller DE. The mechanisms of action of PPARs. Annu Rev Med. 2002;53:409-35

27. Peters JM, Hollingshead HE, Gonzalez FJ. Role of peroxisome-proliferatoractivated receptor $\beta / \delta(P P A R \beta / \delta)$ in gastrointestinal tract function and disease. Clin Sci (Lond). 2008;115:107-27.

28. Willson TMB, Peter J, Daniel D, Sternbach A, Henke BR. The PPARs: from orphan receptors to drug discoveryt; 2000.

29. J Berger, Moller DE: The Mechanisms of Action of PPARs. https://doiorg/ 101146/annurevmed530829011040182003.

30. Chandra V, Huang P, Hamuro Y, Raghuram S, Wang Y, Burris TP, Rastinejad F. Structure of the intact PPAR- $\gamma-R X R-a$ nuclear receptor complex on DNA 2008. p. 456

31. Kersten S, Desvergne B, Wahli W. Roles of PPARs in health and disease; 2000. p. 405.

32. Bility M, Thompson J, McKee R, David R, Butala J, Vanden Heuvel J, Peters J. Activation of mouse and human peroxisome proliferator-activated receptors (PPARs) by phthalate monoesters. Toxicol Sci. 2004;82:170-82.

33. Jonker JW, Suh JM, Atkins AR, Ahmadian M, Li P, Whyte J, He M, Juguilon H, Yin Y-Q, Phillips CT, et al. A PPARY-FGF1 axis is required for adaptive adipose remodelling and metabolic homeostasis. Nature. 2012;485:391.

34. Jeninga EH, Bugge A, Nielsen R, Kersten S, Hamers N, Dani C, Wabitsch M, Berger R, Stunnenberg HG, Mandrup S, Kalkhoven E. Peroxisome proliferator-activated receptor gamma regulates expression of the antilipolytic G-protein-coupled receptor 81 (GPR81/Gpr81). J Biol Chem. 2009; 284:26385-93.

35. Hiuge A, Tenenbaum A, Maeda N, Benderly M, Kumada M, Fisman Enrique Z, Tanne D, Matas Z, Hibuse T, Fujita K, et al. Effects of peroxisome proliferator-activated receptor ligands, Bezafibrate and Fenofibrate, on Adiponectin level. Arterioscler Thromb Vasc Biol. 2007:27:635-41.

36. Lefebvre P, Chinetti G, Fruchart J-C, Staels B. Sorting out the roles of PPAR alpha in energy metabolism and vascular homeostasis. J Clin Invest. 2006; 116:571-80.

37. Brandt JM, Djouadi F, Kelly DP. Fatty acids activate transcription of the muscle Carnitine Palmitoyltransferase I gene in cardiac Myocytes via the peroxisome proliferator-activated receptor a. J Biol Chem. 1998;273: 23786-92.

38. Tontonoz P, Hu E, Spiegelman BM. Stimulation of adipogenesis in fibroblasts by PPARY2, a lipid-activated transcription factor. Cell. 1994;79: 1147-56.

39. Rosen ED, Sarraf P, Troy AE, Bradwin G, Moore K, Milstone DS, Spiegelman $\mathrm{BM}$, Mortensen RM. PPARy is required for the differentiation of adipose tissue in vivo and in vitro. Mol Cell. 1999;4:611-7.

40. Barak Y, Nelson MC, Ong ES, Jones YZ, Ruiz-Lozano P, Chien KR, Koder A, Evans RM. PPARy is required for placental, cardiac, and adipose tissue development. Mol Cell. 1999:4:585-95.

41. Straus D, Glass C. Cyclopentenone prostaglandins: new insights on biological activities and cellular targets. Med Res Rev. 2001;21:185-210.

42. Li X, Ycaza J, Blumberg B. The environmental obesogen tributyltin chloride acts via peroxisome proliferator activated receptor gamma to induce adipogenesis in murine 3T3-L1 preadipocytes. J Steroid Biochem Mol Biol. 2011;127:9-15.

43. Grun F, Watanabe H, Zamanian Z, Maeda L, Arima K, Cubacha R, Gardiner DM, Kanno J, Iguchi T, Blumberg B. Endocrine-disrupting organotin compounds are potent inducers of adipogenesis in vertebrates. Mol Endocrinol. 2006;20:2141-55.

44. Sv K, Kieu T, Chow C, Casey S, Blumberg B. Prenatal exposure to the environmental Obesogen Tributyltin predisposes multipotent stem cells to become adipocytes. Mol Endocrinol. 2010;24:526-39.

45. Shoucri BM, Martinez ES, Abreo TJ, Hung VT, Moosova Z, Shioda T, Blumberg $B$. Retinoid $X$ receptor activation alters the chromatin landscape to commit Mesenchymal stem cells to the adipose lineage. Endocrinology. 2017:158:3109-25.

46. Directorate E. OECDD (organisation for economic cooperation and development); 2004.

47. Krishnan AV, Stathis P, Permuth SF, Tokes L, Feldman D. Bisphenol-a: an estrogenic substance is released from polycarbonate flasks during autoclaving. Endocrinology. 1993;132:2279-86

48. Rubin BS, Soto AM. Bisphenol a: perinatal exposure and body weight. Mol Cell Endocrinol. 2009;304:55-62.

49. Li X, Pham HT, Janesick AS, Blumberg B. Triflumizole is an Obesogen in mice that acts through peroxisome proliferator activated receptor gamma (PPARY). Environ Health Perspect. 2012;120:1720-6.

50. Hurst CH, Waxman DJ. Activation of PPAR alpha and PPAR gamma by environmental phthalate monoesters. Toxicol Sci. 2003:74:297-308.

51. Pillai H, Fang M, Beglov D, Kozakov D, Vajda S, Stapleton H, Webster T, Schlezinger J. Ligand binding and activation of PPAR gamma by Firemaster (R) 550: effects on Adipogenesis and Osteogenesis in vitro. Environ Health Perspect. 2014;122:1225-32.

52. Temkin A, Bowers R, Magaletta M, Holshouser S, Maggi A, Ciana P, Guillette L, Bowden J, Kucklick J, Baatz J, Spyropoulos D. Effects of crude oil/dispersant mixture and dispersant components on PPAR gamma activity in vitro and in vivo: identification of Dioctyl sodium Sulfosuccinate (DOSS; CAS \#577-11-7) as a probable Obesogen. Environ Health Perspect. 2016;124:112-9.

53. Veiga FMS, Graus-Nunes F, Rachid TL, Barreto AB, Mandarim-de-Lacerda CA, Souza-Mello V. Anti-obesogenic effects of WY14643 (PPAR-alpha agonist): hepatic mitochondrial enhancement and suppressed lipogenic pathway in diet-induced obese mice. Biochimie. 2017:140:106-16.

54. Han L, Shen W-J, Bittner S, Kraemer FB, Azhar S. PPARs: regulators of metabolism and as therapeutic targets in cardiovascular disease. Part I: PPAR-a. Futur Cardiol. 2017;13:259-78.

55. Azhar S. Peroxisome proliferator-activated receptors, metabolic syndrome and cardiovascular disease. Futur Cardiol. 2010;6:657-91.

56. Yessoufou A, Atègbo J-M, Attakpa E, Hichami A, Moutairou K, Dramane KL, Khan NA. Peroxisome proliferator-activated receptor-a modulates insulin gene transcription factors and inflammation in adipose tissues in mice. Mol Cell Biochem. 2008;323:101.

57. Collison KS, Makhoul NJ, Zaidi MZ, Inglis A, Andres BL, Ubungen R, Saleh S, Al-Mohanna FA. Prediabetic changes in gene expression induced by aspartame and monosodium glutamate in trans fat-fed C57BI/6 J mice. Nutrition \& metabolism. 2013;10:44

58. Al M, Grimaldi M, Roecklin D, Dagnino S, Vivat-Hannah V, Balaguer P, Bourguet W. Activation of RXR-PPAR heterodimers by organotin environmental endocrine disruptors. EMBO Rep. 2009;10:367-73.

59. Chamorro-García R, Sahu M, Abbey Rachelle J, Laude J, Pham N Blumberg B. Transgenerational inheritance of increased fat depot size, 
stem cell reprogramming, and hepatic Steatosis elicited by prenatal exposure to the Obesogen Tributyltin in mice. Environ Health Perspect. 2013;121:359-66.

60. Schmidt J-S, Schaedlich K, Fiandanese N, Pocar P, Fischer B. Effects of Di (2ethylhexyl) phthalate (DEHP) on female fertility and Adipogenesis in $\mathrm{C} 3 \mathrm{H} / \mathrm{N}$ mice. Environ Health Perspect. 2012;120:1123-9.

61. Gapstur SM, Gann PH, Kopp P, Colangelo L, Longcope C, Liu K. Serum androgen concentrations in young men: a longitudinal analysis of associations with age, obesity, and race. The CARDIA male hormone study. Cancer Epidemiol Biomark Prev. 2002;11:1041-7.

62. Pan G, Hanaoka T, Yoshimura M, Zhang S, Wang P, Tsukino H, Inoue K, Nakazawa H, Tsugane S, Takahashi K. Decreased serum free testosterone in workers exposed to high levels of di-n-butyl phthalate (DBP) and di-2ethylhexyl phthalate (DEHP): a cross-sectional study in China. Environ Health Perspect. 2006;114:1643-8.

63. Heindel JJ. History of the Obesogen field: looking Back to look forward. Front Endocrinol. 2019;10:14.

64. Zoeller RT. Environmental chemicals impacting the thyroid: targets and consequences. Thyroid. 2007:17:811-7.

65. Knudsen N, Laurberg P, Rasmussen LB, Bulow I, Perrild H, Ovesen L, Jorgensen T. Small differences in thyroid function may be important for body mass index and the occurrence of obesity in the population. J Clin Endocrinol Metab. 2005;90:4019-24

66. D'Souza AM, Neumann UH, Glavas MM, Kieffer TJ. The glucoregulatory actions of leptin. Mol Metab. 2017;6:1052-65.

67. Zhang Y, Proenca R, Maffei M, Barone M, Leopold L, Friedman JM. Positional cloning of the mouse obese gene and its human homologue. Nature. 1994 372:425-32.

68. Farr OM, Gavrieli A, Mantzoros CS. Leptin applications in 2015: what have we learned about leptin and obesity? Curr Opinion Endocrinol Diab Obesity. 2015;22:353-9

69. Woodward L, Akoumianakis I, Antoniades C. Unravelling the adiponectin paradox: novel roles of adiponectin in the regulation of cardiovascular disease. Br J Pharmacol. 2017:174:4007-20.

70. Scherer PE, Williams S, Fogliano M, Baldini G, Lodish HF. A novel serum protein similar to C1q, Produced Exclusively in Adipocytes. J Biol Chem. 1995;270:26746-9.

71. Chamorro-Garcia R, Diaz-Castillo C, Shoucri BM, Kach H, Leavitt R, Shioda T, Blumberg B. Ancestral perinatal obesogen exposure results in a transgenerational thrifty phenotype in mice. Nat Commun. 2017:8:2012.

72. Yan H, Guo H, Cheng D, Kou R, Zhang C, Si J. Tributyltin reduces the levels of serum adiponectin and activity of AKT and induces metabolic syndrome in male mice. Environ Toxicol. 2018;33:752-8.

73. Temkin AM, Bowers RR, Ulmer CZ, Penta K, Bowden JA, Nyland J, Baatz JE, Spyropoulos DD. Increased adiposity, inflammation, metabolic disruption and dyslipidemia in adult male offspring of DOSS treated C57BL/6 dams. Sci Rep. 2019;9:1530.

74. Penza M, Montani C, Romani A, Vignolini P, Pampaloni B, Tanini A, Brandi ML, Alonso-Magdalena P, Nadal A, Ottobrini L, et al. Genistein affects adipose tissue deposition in a dose-dependent and gender-specific manner. Endocrinology. 2006;147:5740-51

75. Gu H, Liu Y, Wang W, Ding L, Teng W, Liu L. In utero exposure to di-(2ethylhexyl) phthalate induces metabolic disorder and increases fat accumulation in visceral depots of C57BL/6J mice offspring. Exp Therapeutic Med. 2016;12:3806-12

76. Yin L, Yu KS, Lu K, Yu X. Benzyl butyl phthalate promotes adipogenesis in 3T3-L1 preadipocytes: a high content Cellomics and metabolomic analysis. Toxicol in Vitro. 2016;32:297-309.

77. Lee RA, Harris CA, Wang J-C. Glucocorticoid receptor and adipocyte biology. Nuclear Receptor Res. 2018;5:101373.

78. Sargis RM, Johnson DN, Choudhury RA, Brady MJ. Environmental endocrine disruptors promote adipogenesis in the 3T3-L1 cell line through glucocorticoid receptor activation. Obesity (Silver Spring). 2010;18(7):1283-8.

79. Toubal A, Treuter E, Clément K, Venteclef N. Genomic and epigenomic regulation of adipose tissue inflammation in obesity. Trends in Endocrinol Metab. 2013:24:625-34

80. de Araújo JFP, Podratz PL, Sena GC, Merlo E, Freitas-Lima LC, Ayub JGM, Pereira AFZ, Santos-Silva AP, Miranda-Alves L, Silva IV, Graceli JB. The obesogen tributyltin induces abnormal ovarian adipogenesis in adult female rats. Toxicol Lett. 2018:295:99-114.
81. Sena GC, Freitas-Lima LC, Merlo E, Podratz PL, de Araújo JFP, Brandão PAA, Carneiro MTWD, Zicker MC, Ferreira AVM, Takiya CM, et al. Environmental obesogen tributyltin chloride leads to abnormal hypothalamic-pituitarygonadal axis function by disruption in kisspeptin/leptin signaling in female rats. Toxicol Appl Pharmacol. 2017;319:22-38.

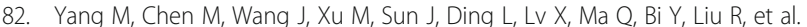
Bisphenol a promotes adiposity and inflammation in a nonmonotonic doseresponse way in 5-week-old male and female C57BL/6J mice fed a lowcalorie diet. Endocrinology. 2016;157:2333-45.

83. Manteiga S, Lee K. Monoethylhexyl phthalate elicits an inflammatory response in adipocytes characterized by alterations in lipid and cytokine pathways. Environ Health Perspect. 2017;125:615-22.

84. Lu X, Luo S, Li H, Zhang X, Wu M, Du Z, Zhu Q, Shen T. Effects of IL-17 antibody on inflammation of adipose tissue in obese mice induced by bisphenol A. Wei Sheng Yan Jiu. 2018;47:945-55.

85. Veiga-Lopez A, Moeller J, Sreedharan R, Singer K, Lumeng C, Ye W, Pease A, Padmanabhan $\mathrm{V}$. Developmental programming: interaction between prenatal BPA exposure and postnatal adiposity on metabolic variables in female sheep. Am J Phys Endocrinol Metab. 2016:310:E238-47.

86. Malaisé Y, Menard S, Cartier C, Gaultier E, Lasserre F, Lencina C, Harkat C, Geoffre N, Lakhal L, Castan I, et al. Gut dysbiosis and impairment of immune system homeostasis in perinatally-exposed mice to Bisphenol a precede obese phenotype development. Sci Rep. 2017;7:14472.

87. Ampem G, Junginger A, Yu H, Balogh L, Thuróczy J, Schneider ME, Röszer T. The environmental obesogen bisphenol a increases macrophage selfrenewal. Cell Tissue Res. 2019;378:81-96.

88. Welch JS, Ricote M, Akiyama TE, Gonzalez FJ, Glass CK. PPARgamma and PPARdelta negatively regulate specific subsets of lipopolysaccharide and IFN-gamma target genes in macrophages. Proc Natl Acad Sci U S A. 2003; 100:6712-7.

89. Jiang C, Ting AT, Seed B. PPAR- $\gamma$ agonists inhibit production of monocyte inflammatory cytokines. Nature. 1998;391:82-6.

90. Ricote M, Li AC, Willson TM, Kelly CJ, Glass CK. The peroxisome proliferatoractivated receptor- $\gamma$ is a negative regulator of macrophage activation. Nature. 1998;391:79-82.

91. Ricote M, Glass C. PPARs and molecular mechanisms of transrepression. Biochimica et Biophysica Acta (BBA) - Molecular and Cell Biology of Lipids. 2007:1771:926-35.

92. Devchand PR, Keller H, Peters JM, Vazquez M, Gonzalez FJ, Wahli W. The PPARa-leukotriene B4 pathway to inflammation control. Nature. 1996;384: 39-43.

93. Szalkowski D, White-Carrington S, Berger J, Zhang B. Antidiabetic thiazolidinediones block the inhibitory effect of tumor necrosis factor-alpha on differentiation, insulin-stimulated glucose uptake, and gene expression in 3T3-L1 cells. Endocrinology. 1995;136:1474-81.

94. Lehmann JM, Moore LB, Smith-Oliver TA, Wilkison WO, Willson TM, Kliewer SA. An Antidiabetic thiazolidinedione is a high affinity ligand for peroxisome proliferator-activated receptor Y (PPARY). J Biol Chem. 1995;270:12953-6.

95. Kanayama T, Kobayashi N, Mamiya S, Nakanishi T, Nishikawa J. Organotin compounds promote adipocyte differentiation as agonists of the peroxisome proliferator-activated receptor gamma/retinoid $X$ receptor pathway. Mol Pharmacol. 2005;67:766-74.

96. Inadera $\mathrm{H}$, Shimomura $\mathrm{A}$. Environmental chemical tributyltin augments adipocyte differentiation. Toxicol Lett. 2005;159:226-34.

97. Pereira-Fernandes A, Vanparys C, Hectors T, Vergauwen L, Knapen D, Jorens $P$, Blust R. Unraveling the mode of action of an obesogen: mechanistic analysis of the model obesogen tributyltin in the 3T3-L1 cell line. Mol Cell Endocrinol. 2013;370:52-64.

98. Pereira-Fernandes A, Demaegdt H, Vandermeiren $K$, Hectors TLM, Jorens PG, Blust $R$, Vanparys $C$. Evaluation of a screening system for obesogenic compounds: screening of endocrine disrupting compounds and evaluation of the PPAR dependency of the effect. PLoS One. 2013;8.

99. Bastos Sales L, Kamstra JH, Cenijn PH, van Rijt LS, Hamers T, Legler J. Effects of endocrine disrupting chemicals on in vitro global DNA methylation and adipocyte differentiation. Toxicol In Vitro. 2013;27:1634-43.

100. Chamorro-Garcia R, Kirchner S, Li X, Janesick A, Casey S, Chow C, Blumberg B. Bisphenol A Diglycidyl ether induces Adipogenic differentiation of multipotent stromal stem cells through a peroxisome proliferator-activated receptor gamma-independent mechanism. Environ Health Perspect. 2012; 120:984-9. 
101. Masuno H, Okamoto S, Iwanami J, Honda K, Shiosaka T, Kidani T, Sakayama $\mathrm{K}$, Yamamoto $\mathrm{H}$. Effect of 4-Nonylphenol on cell proliferation and adipocyte formation in cultures of fully differentiated 3T3-L1 cells. Toxicol Sci. 2003;75: 314-20.

102. Helies-Toussaint C, Peyre L, Costanzo C, Chagnon M, Rahmani R. Is bisphenol $\mathrm{S}$ a safe substitute for bisphenol a in terms of metabolic function? An in vitro study. Toxicol Appl Pharmacol. 2014;280:224-35.

103. Harmon A, Harp J. Differential effects of flavonoids on 3T3-L1 adipogenesis and lipolysis. Am J Phys Cell Phys. 2001;280:C807-13.

104. Saito T, Abe D, Sekiya K. Flavanone exhibits PPAR gamma ligand activity and enhances differentiation of 3T3-L1 adipocytes. Biochem Biophys Res Commun. 2009;380:281-5.

105. Takahashi N, Goto T, Taimatsu A, Egawa K, Katoh S, Kusudo T, Sakamoto T, Ohyane C, Lee J, Kim Y, et al. Bixin regulates mRNA expression involved in adipogenesis and enhances insulin sensitivity in 3T3-L1 adipocytes through PPAR gamma activation. Biochem Biophys Res Commun. 2009;390:1372-6.

106. Yang $Y$, Shang $W$, Zhou $L$, Jiang $B$, Jin $H$, Chen $M$. Emodin with PPAR gamma ligand-binding activity promotes adipocyte differentiation and increases glucose uptake in 3T3-LI cells. Biochem Biophys Res Commun. 2007; 353:225-30

107. Feige J, Gelman L, Rossi D, Zoete V, Metivier R, Tudor C, Anghel S, Grosdidier A, Lathion C, Engelborghs Y, et al. The endocrine disruptor monoethyl-hexyl-phthalate is a selective peroxisome proliferator-activated receptor gamma modulator that promotes adipogenesis. J Biol Chem. 2007; 282:19152-66

108. Salam NK, Huang THW, Kota BP, Kim MS, Li YH, Hibbs DE. Novel PPARgamma agonists identified from a natural product library: a virtual screening, induced-fit docking and biological assay study. Chem Biol Drug Des. 2008;71:57-70.

109. Shannon M, Wilson J, Xie Y, Connolly L. In vitro bioassay investigations of suspected obesogen monosodium glutamate at the level of nuclear receptor binding and steroidogenesis. Toxicol Lett. 2019;301:11-6.

110. Dang Z, Audinot V, Papapoulos S, Boutin J, Lowik C. Peroxisome proliferator-activated receptor gamma (PPAR gamma) as a molecular target for the soy phytoestrogen genistein. J Biol Chem. 2003;278:962-7.

111. Wang RY, Abbott RD, Zieba A, Borowsky FE, Kaplan DL. Development of a three-dimensional adipose tissue model for studying embryonic exposures to obesogenic chemicals. Ann Biomed Eng. 2017;45:1807-18.

112. Choi J, Gimble J, Vunjak-Novakovic G, Kaplan D. Effects of Hyperinsulinemia on Lipolytic function of three-dimensional adipocyte/endothelial cocultures. Tissue Engineering Part C-Methods. 2010;16:1157-65.

113. Bellas E, Marra K, Kaplan D. Sustainable three-dimensional tissue model of human adipose tissue. Tissue Engineering Part C-Methods. 2013;19:745-54.

114. Kato S, Kato Y, Shibata H, Saitoh Y, Miwa N. Repressive effects of oat extracts on intracellular lipid-droplet formation in adipocytes and a threedimensional subcutaneous adipose tissue model. Materials Sci Engineering C-Materials For Biol Appl. 2015;49:269-73.

115. Krontiras P, Gatenholm P, Hagg D. Adipogenic differentiation of stem cells in three-dimensional porous bacterial nanocellulose scaffolds. J Biomed Materials Res Part B-Appl Biomaterials. 2015;103:195-203.

116. Kang X, Xie Y, Kniss D. Adipose tissue model using three-dimensional cultivation of preadipocytes seeded onto fibrous polymer scaffolds. Tissue Eng. 2005;11:458-68

117. Frye C, Patrick C. Three-dimensional adipose tissue model using low shear bioreactors. In Vitro Cellular \& Dev Biol Animal. 2006;42:109-14.

118. Fischbach C, Seufert J, Staiger H, Hacker M, Neubauer M, Gopferich A, Blunk T. Three-dimensional in vitro model of adipogenesis: comparison of culture conditions. Tissue Eng. 2004;10:215-29.

119. Daquinag A, Souza G, Kolonin M. Adipose tissue engineering in threedimensional levitation tissue culture system based on magnetic nanoparticles. Tissue Engineering Part C-Methods. 2013;19:336-44.

120. Hartman JK, Beames T, Parks B, Doheny D, Song G, Efremenko A, Yoon M, Foley B, Deisenroth C, McMullen PD, Clewell RA. An in vitro approach for prioritization and evaluation of chemical effects on glucocorticoid receptor mediated adipogenesis. Toxicol Appl Pharmacol. 2018;355:112-26.

121. Foley B, Doheny DL, Black MB, Pendse SN, Wetmore BA, Clewell RA, Andersen ME, Deisenroth C. Screening ToxCast prioritized chemicals for PPARG function in a human adipose-derived stem cell model of Adipogenesis. Toxicol Sci. 2017;155:85-100.

122. Niedo J, Tanimoto S, Thompson RH, Abbott RD, Berninger WW. Computerized instruction in translation strategies for students in upper elementary and middle school grades with persisting learning disabilities in written language. Learn Disabil (Pittsbg). 2016;21:14-30.

123. Shi H, Clegg DJ. Sex differences in the regulation of body weight. Physiol Behav. 2009:97:199-204.

124. Abbott RD, Wang RY, Reagan MR, Chen Y, Borowsky FE, Zieba A, Marra KG, Rubin JP, Ghobrial IM, Kaplan DL. The use of silk as a scaffold for mature, sustainable Unilocular adipose 3D tissue engineered systems. Adv Healthc Mater. 2016;5:1667-77.

125. Darbre PD. Endocrine disruptors and obesity. Curr Obes Rep. 2017;6:18-27.

126. Bujalska IJ, Kumar S, Hewison M, Stewart PM. Differentiation of adipose stromal cells: the roles of glucocorticoids and 11 beta-hydroxysteroid dehydrogenase. Endocrinology. 1999;140:3188-96.

127. Chamorro-Garcia R, Blumberg B. Current research approaches and challenges in the Obesogen field. Front Endocrinol. 2019;10:167.

128. Hao C, Cheng X, Guo J, Xia H, Ma X. Perinatal exposure to diethyl-hexylphthalate induces obesity in mice. Front Biosci (Elite Ed). 2013;5:725-33.

129. Newbold RR, Padilla-Banks E, Snyder RJ, Jefferson WN. Developmental exposure to estrogenic compounds and obesity. Birth Defects Res A Clin Mol Teratol. 2005;73:478-80.

130. Hao C, Cheng X, Xia H, Ma X. The endocrine disruptor mono-(2-ethylhexyl) phthalate promotes adipocyte differentiation and induces obesity in mice. Biosci Rep. 2012;32:619-29.

131. Yan Z, Zhang H, Maher C, Arteaga-Solis E, Champagne FA, Wu L, McDonald JD, Yan B, Schwartz GJ, Miller RL. Prenatal polycyclic aromatic hydrocarbon, adiposity, peroxisome proliferator-activated receptor (PPAR) gamma methylation in offspring, grand-offspring mice. PLoS One. 2014;9:e110706.

132. Bolton JL, Auten RL, Bilbo SD. Prenatal air pollution exposure induces sexually dimorphic fetal programming of metabolic and neuroinflammatory outcomes in adult offspring. Brain Behav Immun. 2014;37:30-44.

133. La Merrill M, Karey E, Moshier E, Lindtner C, La Frano MR, Newman JW, Buettner C. Perinatal exposure of mice to the pesticide DDT impairs energy expenditure and metabolism in adult female offspring. PLoS One. 2014;9: e103337.

134. Maull EA, Ahsan H, Edwards J, Longnecker MP, Navas-Acien A, Pi JB, Silbergeld EK, Styblo M, Tseng CH, Thayer KA, Loomis D. Evaluation of the association between arsenic and diabetes: a National Toxicology Program Workshop Review. Environ Health Perspect. 2012;120:1658-70.

135. Nguyen TLA, Vieira-Silva S, Liston A, Raes J. How informative is the mouse for human gut microbiota research? Dis Model Mech. 2015;8:1-16.

136. Monteiro R, Azevedo I. Chronic inflammation in obesity and the metabolic syndrome. Mediat Inflamm. 2010;2010.

137. Strakovsky RS, Lezmi S, Shkoda I, Flaws JA, Helferich WG, Pan YX. In utero growth restriction and catch-up adipogenesis after developmental di (2-ethylhexyl) phthalate exposure cause glucose intolerance in adult male rats following a high-fat dietary challenge. J Nutr Biochem. 2015; 26:1208-20

138. Somm E, Schwitzgebel VM, Toulotte A, Cederroth CR, Combescure C, Nef S, Aubert ML, Huppi PS. Perinatal exposure to bisphenol a alters early adipogenesis in the rat. Environ Health Perspect. 2009;117:1549-55.

139. Badr El Dine FMM, Nabil IM, Dwedar FI. The effect of Tributyltin on thyroid follicular cells of adult male albino rats and the possible protective role of green tea: a toxicological, histological and biochemical study. Egypt J Forensic Sci. 2017:7:7.

140. Green AJ, Hoyo C, Mattingly CJ, Luo Y, Tzeng JY, Murphy SK, Buchwalter DB, Planchart A. Cadmium exposure increases the risk of juvenile obesity: a human and zebrafish comparative study. Int J Obes. 2018;42:1285-95.

141. Lyssimachou A, Santos JG, Andre A, Soares J, Lima D, Guimaraes L, Almeida CM, Teixeira C, Castro LF, Santos MM. The mammalian "Obesogen" Tributyltin targets hepatic triglyceride accumulation and the transcriptional regulation of lipid metabolism in the liver and brain of Zebrafish. PLoS One. 2015;10:1-22.

142. Tingaud-Sequeira A, Ouadah N, Babin PJ. Zebrafish obesogenic test: a tool for screening molecules that target adiposity. J Lipid Res. 2011;52:1765-72

143. Punzon I, Latapie V, Le Mevel S, Hagneau A, Jolivet P, Palmier K, Fini JB, Demeneix BA. Towards a humanized PPAR gamma reporter system for in vivo screening of obesogens. Mol Cell Endocrinol. 2013;374:1-9.

144. Rhrissorrakrai K, Belcastro V, Bilal E, Norel R, Poussin C, Mathis C, Dulize $\mathrm{RH}$, Ivanov NV, Alexopoulos L, Rice JJ, et al. Understanding the limits of animal models as predictors of human biology: lessons learned from the sbv IMPROVER species translation challenge. Bioinformatics. 2015;31: 471-83. 
145. Hatch EE, Nelson JW, Stahlhut RW, Webster TF. Association of endocrine disruptors and obesity: perspectives from epidemiological studies. Int J Androl. 2010;33:324-32.

146. Buckley JP, Engel SM, Braun JM, Whyatt RM, Daniels JL, Mendez MA, Richardson DB, Xu YY, Calafat AM, Wolff MS, et al. Prenatal phthalate exposures and body mass index among 4-to 7-year-old children: a pooled analysis. Epidemiology. 2016;27:449-58.

147. Valvi D, Casas M, Mendez MA, Ballesteros-Gomez A, Luque N, Rubio S, Sunyer J, Vrijheid M. Prenatal Bisphenol a urine concentrations and early rapid growth and overweight risk in the offspring. Epidemiology. 2013;24: 791-9.

148. Braun Joseph M, Gennings C, Hauser R, Webster Thomas F. What can epidemiological studies tell us about the impact of chemical mixtures on human health? Environ Health Perspect. 2016;124:A6-9.

149. Needham LL, Calafat AM, Barr DB. Assessing developmental toxicant exposures via biomonitoring. Basic \& clinical pharmacology \& toxicology 2008:102:100-8.

150. Savitz DA. Invited commentary: interpreting associations between exposure biomarkers and pregnancy outcome. Am J Epidemiol. 2014;179:545-7.

151. Sharpe RM, Drake AJ. Obesogens and obesity—an alternative view? Obesity. 2013;21:1081-3.

\section{Publisher's Note}

Springer Nature remains neutral with regard to jurisdictional claims in published maps and institutional affiliations.

Ready to submit your research? Choose BMC and benefit from:

- fast, convenient online submission

- thorough peer review by experienced researchers in your field

- rapid publication on acceptance

- support for research data, including large and complex data types

- gold Open Access which fosters wider collaboration and increased citations

- maximum visibility for your research: over $100 \mathrm{M}$ website views per year

At BMC, research is always in progress.

Learn more biomedcentral.com/submissions 